\title{
CHALLENGES OF DEPOPULATION IN LATVIA'S RURAL AREAS
}

Aleksandrs Dahs' ${ }^{1}$, Dr.demog.; Atis Berzins ${ }^{2}$, Dr.oec.; Juris Krumins ${ }^{3}$, Dr.habil.oec.

\author{
1, 2, 3University of Latvia
}

Abstract. The administrative territorial reform of 2021 in Latvia has changed the shape and structure of local municipalities. Previous studies have shown that disparities and challenges in terms of demographic development will be even more evident between the newly formed municipalities than they were prior to the reform, creating greater demographic risks for the rural areas. By using the available statistical information and geographically weighted regression models, this study aims to evaluate the demographic challenges in Latvia's rural areas and to determine main socio economic factors linked to the rural depopulation processes. Key indicators linked to the depopulation process are evaluated and discussed by the authors in the context of gender balance, development centre accessibility and other socio economic factors. Authors conclude that supporting and developing local industries, public services and infrastructure facilitating diverse employment options and equal opportunities for working age females is a paramount condition for slowing or reversing rural depopulation in in the long term. Regional development centres in general and particularly those located in remote areas show little or no immediate effect on the population dynamics. However, these centres offer more diverse employment opportunities and essential social services, making them more attractive to working age females and households with children. Digitalisation and focus on location-independent employment and services is another important route to explore in the new rural development setting.

Key words: regional demography, depopulation, spatial modelling.

JEL code: J11, I38, R11

\section{Introduction}

According to the UN estimate, 2007 was the year when, for the first time, a number of the world rural population dropped behind a number of urban population (UN, 2018). In Latvia, it occurred in the year 1954 (CSB, 1961). In spite of higher fertility level in rural areas, due to rural-urban internal migration number of rural inhabitants continued systematically to decline and reached 601.5 thousand in 2020 or 31.5 per cent of the total population of Latvia (CSB, 2020). According to that figure, Latvia is not considered as highly urbanized country. Share of the world population living in rural areas as estimated by the European Commission is $15 \%$, but in Europe, it is $26.5 \%$. The European Commission combines satellite imagery with national census data to derive urban and rural populations based on its own standardized definitions. This result differs from UN figures, which are based on nationally defined urban definitions (Ritchie, $H$. and Roser, M., 2019). It should be noted that there is no universal criterion of urban or rural area (Dijkstra, L. and Poelman, H., 2014).

Lower level of education and health care, tradition of large children families led to rural excess fertility and mortality compared to townsmen during many decennials. In terms of demographic development, many European rural areas face socio-economic challenges. While some areas have good population development prospects, many are actually experiencing a serious population decline. The same applies to the rural municipalities of Latvia. Municipalities located outside the Riga city metropolitan area and lacking access to the development centres show persistent depopulation trends, which are linked to a multitude of socio economic issues. Literature sources show that key factor for demographic development in such areas is their attractiveness for young adults and families, as such territories mostly tend to lose these groups due to out-migration (Cipin I. et al, 2020).

The administrative territorial reform of 2021 in Latvia has changed the shape and structure of the local municipalities (Saeima, 2020). The new municipal structure may prove to be more robust and manageable, 
linking rural municipalities and their respective regional development centres. However, disparities and challenges in terms of demographic development will persist between the newly formed municipalities (Krumins J. et al, 2020). These changes necessitate a better understanding of determinants and consequences of depopulation processes in rural municipalities in order to evaluate the effectiveness of any potential future corrective or coping policy measures.

This study aims to evaluate the demographic challenges in Latvia's rural areas and to determine main socio economic factors linked to the rural depopulation processes.

By using available statistical information, geospatial data and geographically weighted regression models authors evaluate demographic indicators on the local level, while paying particular attention to the local socio economic. Statistical and geographical data used in this study come from Central Statistics Bureau of Latvia, State Land Service, Ministry of Environmental Protection and Regional Development datasets, as well as referenced studies on related topics.

It is important to highlight that there are two types of development centres recognised under the national regulations - centres of national significance and centres of regional significance. Considering the planned changes introduced under the administrative-territorial reform, for the purpose of this study such distinction is not critical. With this in mind, hereafter we label centres of both types simply as "regional development centres".

\section{Research results and discussion}

We begin this paper by describing the data used for this research and reviewing scientific literature dealing with various aspects of rural depopulation. In the second section proceed with statistical and geographical analysis of the main regional demographic trends within the pre-reform and post-reform administrative framework. Third section provides model-based assessment of these trends, placing them in the context of socio economic conditions and other local specifics.

\section{Data and literature}

Breakdown of the Latvia's population by urban and rural inhabitants is made by CSB according to their permanent place of residence. Urban population refers to those persons who live in cities and towns, i.e. in populated areas with at least 2000 resident population. In a number of historically developed cities, the population may be less than 2000 . Status of a city and town is assigned and cancelled by the Saeima with a law. All the rest is considered rural population (CSB, 2020a). But rural areas beyond borders of urban administrative territories are inhabited unevenly. 
Rural population in statistical regions of Latvia on 1 January 2020

\begin{tabular}{|l|c|c|c|c|}
\hline \multirow{2}{*}{ Statistical region } & \multicolumn{2}{|c|}{$\begin{array}{c}\text { Population } \\
\text { In rural areas }\end{array}$} & \multicolumn{2}{c|}{$\begin{array}{c}\text { Population in rural type } \\
\text { territories } \\
\text { (sparsely populated areas*) }\end{array}$} \\
\cline { 2 - 5 } & $\begin{array}{c}\text { Thousand } \\
\text { inhabitants }\end{array}$ & $\%$ & $\begin{array}{c}\text { Thousand } \\
\text { inhabitants }\end{array}$ & $\%$ \\
\hline Latvia [60,50]** & 601.5 & 31.5 & 376.5 & 19.7 \\
\hline Riga city [-,-] & - & - & - & - \\
\hline Pieriga region [16,12] & 196.4 & 52.5 & 73.3 & 19,6 \\
\hline Vidzeme region [14,11] & 103.3 & 56.2 & 80.3 & 43.7 \\
\hline Kurzeme region [11,7] & 85.3 & 35.9 & 66.3 & 28.2 \\
\hline Zemgale region [8,12] & 116.8 & 51.1 & 73.2 & 32.0 \\
\hline Latgale region [11,8] & 99.7 & 39.0 & 82.9 & 32.4 \\
\hline
\end{tabular}

* Sparsely populated areas (experimental statistics): Territories outside cities, towns and densely populated areas with at least 500 inhabitants. Experimental statistics is produced by using new data sources and methods in making attempts to expand the range of statistics or the level of detail thereof based on the needs of data users.

** In brackets: number of counties (novads) with and without towns.

\section{Source: authors' elaboration based on CSB, 2021}

Rural population has settled in more than 150 thousand farmsteads, more than 1500 small villages (each less than 40 inhabitants) and 1201 large villages, 21 of which exceed 2000 inhabitants and consist almost 60 per cent of whole rural population (Nikodemus, O. et al., 2018). Therefore, demographic characteristics of the total rural population are pure averages, depending on distances from capital city metropolitan area, development centres and population density. One of alternative ways to study rural population is to distinguish by experimental statistics the population in rural type territories or sparsely populated areas (Table 1). By using this approach, the number of rural population decreases by more than $1 / 3$, and its share in the total population declines to 20 per cent. Particularly significant is the decline of the share of rural population in Pieriga region by 33 per cent points.

The administrative-territorial reform has added new complexities to the regional socio economic and demographic landscape of Latvia. Even greater emphasis is placed on the regional development centres to guide and support their adjacent territories through transition process and facilitate distribution of support funding and other resources (CCC, 2020). Prerequisites of the reform have mandated a more logical population distribution among rural municipalities and better interconnection of rural municipalities with their respective development centres (Saeima, 2020).

Figure 1 shows the location of densely populated areas (see CSB, 2020b) and regional development centres overlain on the pre-reform and post-reform municipal boundaries. 


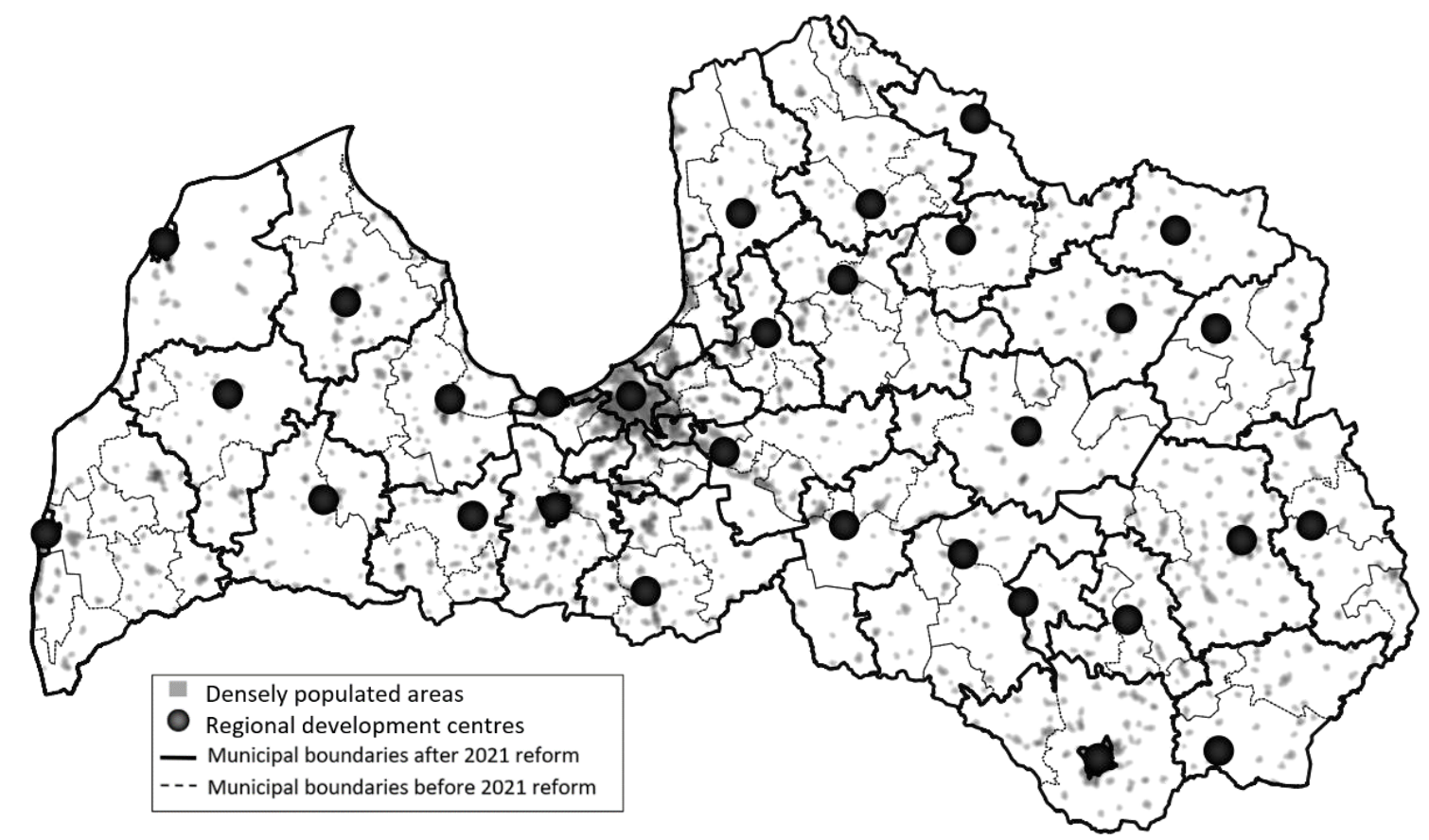

Source: authors' elaboration based on CSB, 2020b; VARAM, 2021 and SLS, 2016

Fig. 1. Densely populated areas and regional development centres in Latvia in 2019 projected upon post-reform and pre-reform municipalities

From the data analysis perspective, this administrative rearrangement has created data challenges due to difficulties in linking statistical indicators and development history of pre-reform and post-reform territories. This problem was partially resolved by a meticulous recalculation of the available spatial data conducted in previous studies (Krumins J. at al, 2020). Available data for post-reform municipalities are still limited and cannot be used for model-based assessments.

For the deeper statistical and model-based analysis, we use various datasets on pre-reform municipalities provided by Central Statistics Bureau of Latvia, State Land Service and Ministry of Environmental Protection and Regional Development. We also rely heavily on previous studies and literature sources dealing with rural depopulation issues in Europe.

A comprehensive overview of the latest research trends addressing rural demographic development throughout Europe can be found in Population Europe Policy Brief No 27 prepared by Ivan Cipin, Sebastian Klusener, Joaquin Recano and Magda Ulceluse (2020). This report indicates several very important points, some of them being particularly relevant to Latvia's rural areas.

For example, Sebastian Klusener in his 2006 study on rural areas of Ukraine has suggested that rural regions in general tend to offer more and better employment opportunities for men than women (Klüsener S., 2006). This finding was recently corroborated by the European Parliament report developed by Ramona Franic and Tihana Kkovacicek (Franic R. and Kovacicek T., 2019). In addition, life course researchers have also found that spatial mobility unavoidable for many rural residents may conflict with other life domains such as family formation and fertility (especially for women), which in turn has negative demographic effects (Ruger, H. and Viry, G., 2017).

Aforementioned studies lead to the conclusion that the higher gender ratio (ratio of males to females in a population) promotes females to leave and younger males unable to form a family. The resulting imbalance in population dynamics lead rural areas to an older age structure along with more serious social, economic and demographic disparities (Hill, K., 2013). We will demonstrate validity of these arguments for Latvia in the next section of this paper. 
Joaquin Recano (2017) proposes to group rural municipalities into three types according to their resilience and risks associated with demographic change. This approach may be easily adopted to the case of Latvia, using these criteria.

- Resilient spaces - certain demographic stability with population densities higher than the rural average and gender ratio is slightly greater than for country as a whole. The impact of emigration is less evident.

- Spaces of emigration have a small number of inhabitants and low population density, negative growth rates, a significantly higher gender ratio than the first group, a relative high level of ageing and major impact of emigration.

- Spaces at risk of irreversible depopulation - with characteristics at the extreme end of the scale: very small number of inhabitants, low population density and maximum ageing.

Furthermore, some authors argue that differentiation of various types of countryside is even more important than search for the definition of the rural against the urban, proposing different country-specific types of classification for rural areas (Stonawska, K. and Vaishar, A., 2018, Hasek, O., 2020).

In terms of possible solutions or mitigation measures to rural depopulation, literature sources provide several key directions for consideration. Most popular suggestions include facilitating stronger social ties (Ermisch, J. and Mulder, C., H. 2019) and improved commuting and digitalisation (Ruger, H. and Viry, G., 2017). Other studies suggest focusing specifically on gender-equal employment opportunities and familyfriendly spaces in an attempt to avoid female out-migration from rural areas (Camarero, L. and Sampedro, R. 2016, Klüsener S., 2006).

It is also worth mentioning that due to the regional differences in age and gender structures, some recent studies have identified rural areas as a special risk group for the negative effects of COVID-19 pandemic (Kashnitsky, I. and Aburto, J. M., 2020).

\section{Demographic challenges before and after the reform}

In this section, we provide statistical and geographical analysis of the regional demographic trends within the pre-reform and post-reform administrative framework, with a particular focus on rural municipalities lacking direct access to the regional development centres prior to the reform. Identified disparities are then discussed in the context of concepts found in the literature.

Figure 2 below shows several key regional demographic indicators for the pre-reform and post-reform municipal structures. Regional development centres are marked identically on all maps.

Most noticeably figures suggest that presence of the regional development centre as such does not seem to have a direct correlation with demographic processes in the adjacent rural regions. The core-periphery effect generated by the capital city Riga and several other major cities can be clearly observed as well, suggesting that accessibility, as well as social and economic diversity of the development centre are essential for the positive demographic impact (BiB, 2018). 

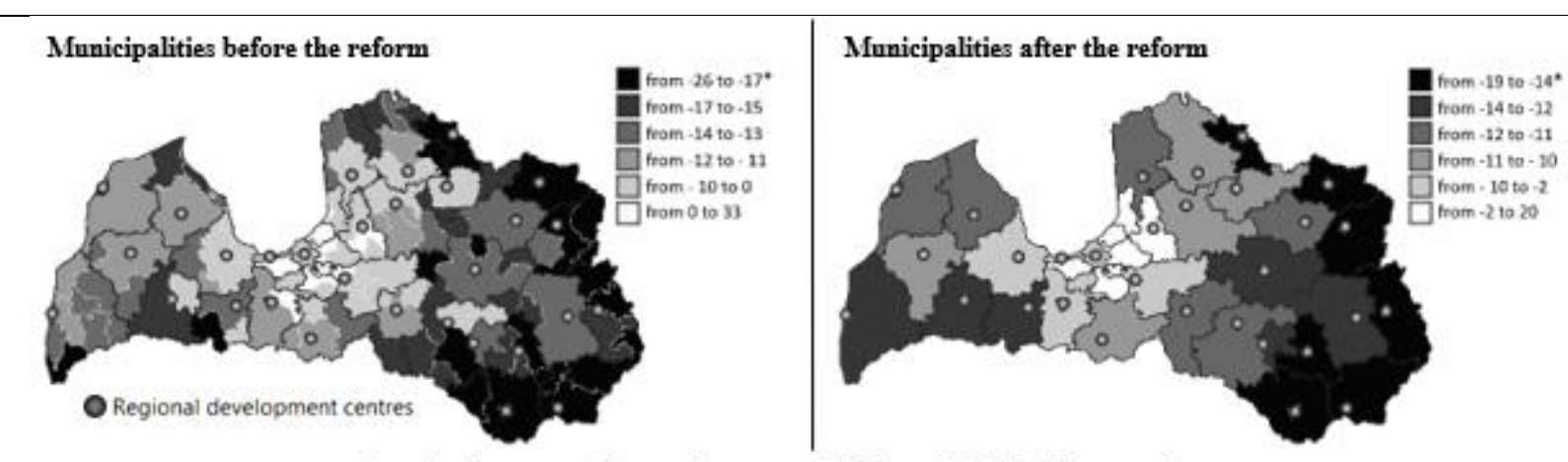

Population growth rate between 2011 and 2019 (six equal

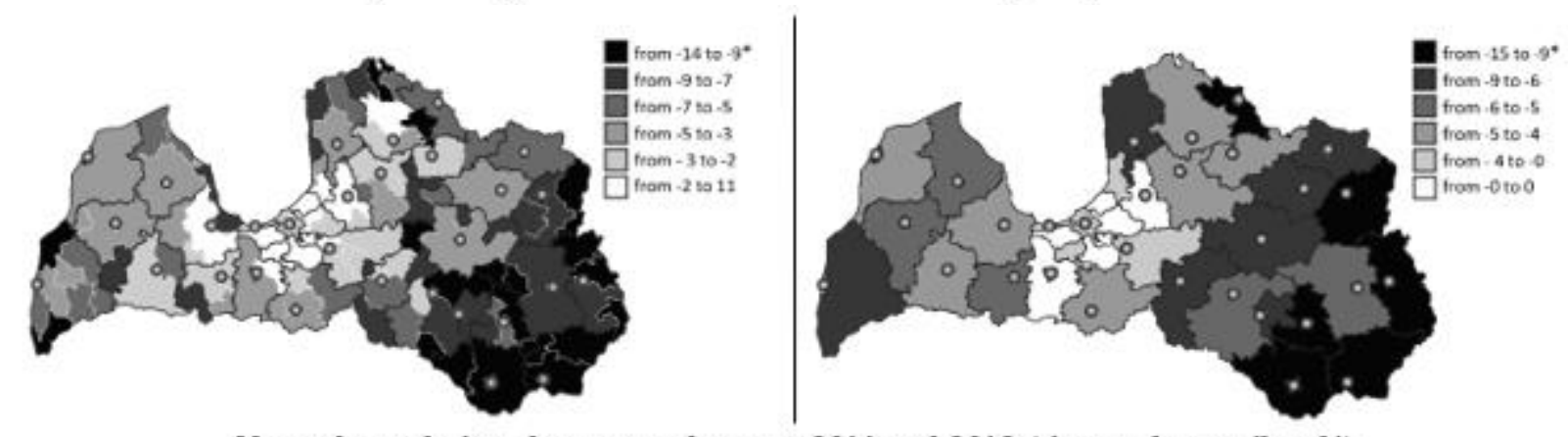

Natural population change rate between 2011 and 2019 (six equal quantiles, \%)

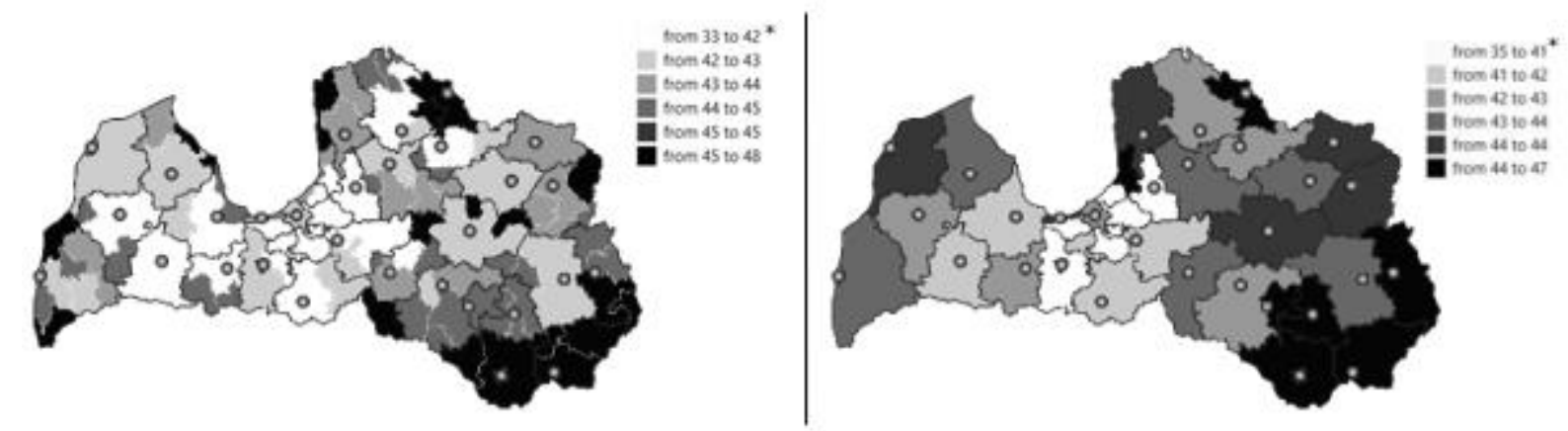

Average population age in 2019 (síx equal quantiles, years)

* Upper interval boundaries included in the intervals

Source: authors' elaboration based on Krumins J. et al, 2020; CSB, 2021; VARAM, 2021 and SLS, 2016

Fig. 2. Key regional demographic indicators for the pre-reform and post-reform municipal structures in Latvia (2011-2019 period)

Figure shows a classical core-periphery distribution of the demographic development trends, suggesting possible categorisation of the municipalities by the associated demographic risks as proposed by Joaquin Recano (2017) and Oldrich Hasek (2020). It is also noticeable that administrative-territorial reform has not affected this core-periphery setting, often merging municipalities facing similar demographic challenges.

Next, we test the concept found in literature regarding the role of gender ratio in the regional demographic processes. It is very important to note that the overall gender ratio in Latvian rural municipalities initially does not match any expectations based on literature review. However, once we account for the life expectancy difference between males and females in senior population groups, the figures match the predictions. For this reason, in this study we use the local gender ratios only for the working age population (hereafter referred as gender ratio).

Figure 3 shows corresponding gender ratios of working age population in 2019. 


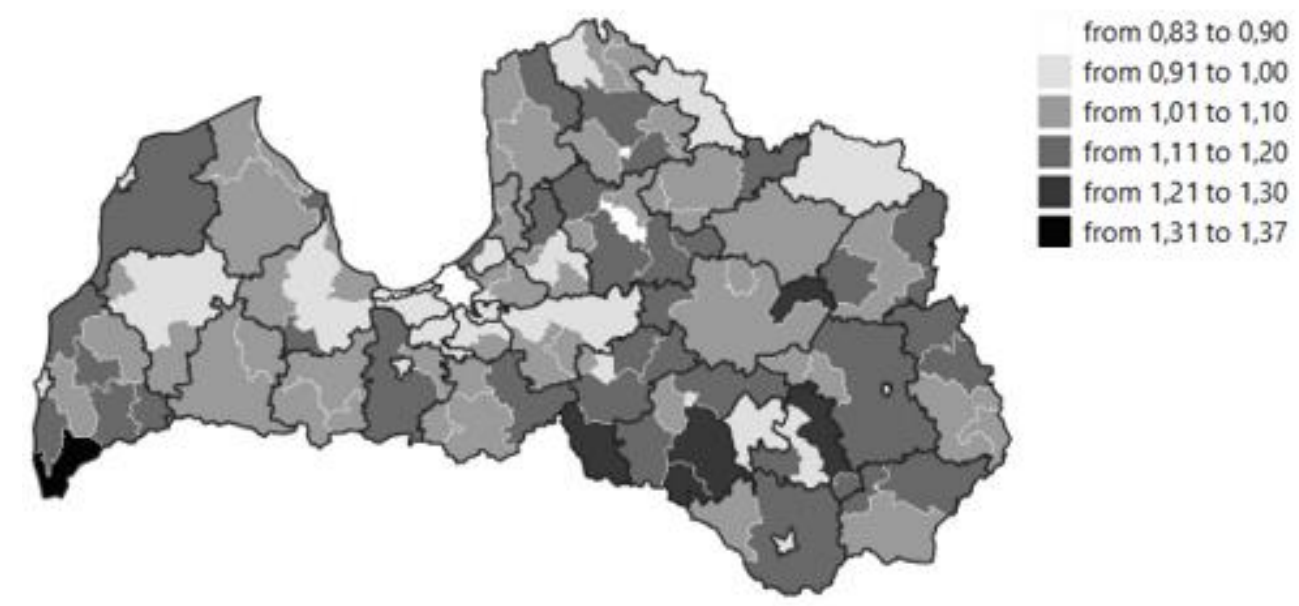

Source: authors' elaboration based on CSB, 2021; and SLS, 2016

Fig. 3. Working age population male to female gender ratio in Latvian pre-reform municipalities in 2019

Comparison of the results shown in Figure 3 with the maps provided in Figure 2 indicates that gender ratios in many local municipalities rather closely reflect the demographic disparities, as predicted by the literature. Some spatial spill-over effects can be observed around capital city and major development centres, where lower gender ratios in the city itself correlates with better demographic situation in the surrounding municipalities as well. This can be attributed to the classical spatial lag effect caused by population mobility. Most noticeable deviations from the predictions can be observed in rural municipalities located on the eastern border, where demographic development is hindered by several other socioeconomic factors.

\section{Social and economic factors of rural depopulation}

In this section, we conduct a model-based assessment of several local socio-economic factors' and regional development centres' role in driving demographic change of rural areas. We use standard Linear Models (LM) to test direct causalities between indicators in municipalities. In cases where spatial spill-overs of the effects between neighbouring municipalities are likely, we also use Spatial Lag Models (SLM) and compare the results of both tests. Information on both model types and their applications for spatial and demographic research is well described in the literature and thus is not included in this paper (Ward, M. D. and Gleditsch, K. S., 2008, Dahs, A., 2017).

It should be noted that the models presented below are experimental in nature and rely on available limited spatially referenced datasets. In some cases, the indicators used in the model may not cover the same time frame.

Previous research on the topic (Dahs, 2017) has already established direct and spatially distributed links between demographic processes and several socio-economic indicators including income and employment. To control for these effects in the models, we use average wages in private sector and unemployment level data. In this study, we also add some new parameters reflecting the presence or direct proximity of a regional development centre (as dummy variable), gender ratios and shares of economically active individuals employed by the specific industry sectors (according to NACE classification). After the model calibration stage, only those industries showing statistically significant demographic effects were selected for the models. To determine the factors affecting gender balance, we use gender ratios as dependant variable in one of the models. 
Figure 4 shows the uneven distribution of average wages in private sector in 2017 and the comparative shares of economically active individuals employed by selected industry sectors. Only private sector wages and the particular industries are shown, as these present much higher significance levels for the indicators under study.

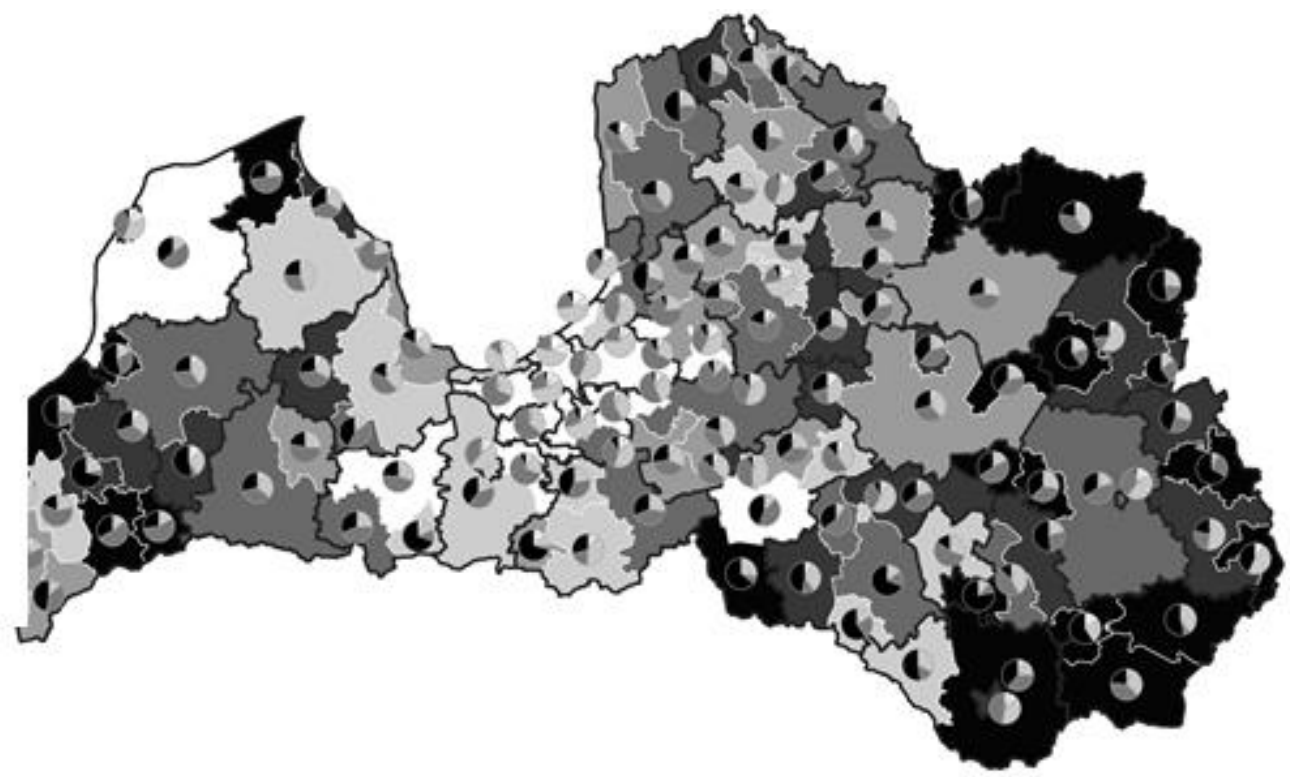

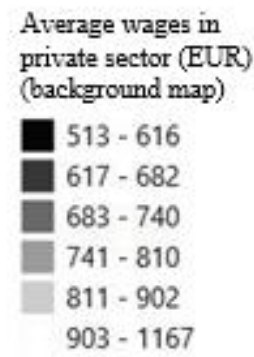

Share of individuals employed (\%) (vie charts)

ICT HOSPITALTY

RETAIL

PRODUCTION

AGRICULTURE

Source: authors' elaboration based on CSB, 2020b; and SLS, 2016

Fig. 4. Average wages in private sector and shares of economically active individuals employed by selected industries in Latvian municipalities in 2017

The visually evident disparities in wage levels and industry roles across municipalities corroborates the feasibility of a further model-based assessment.

Table 2 provides selected results of the LM and SLM estimations featuring the effects of factors mentioned above on the regional demographic indicators - gender ratios, total population growth, net migration and share of residents below working age.

Table 2

Selected results of the experimental model estimations featuring effects of social and economic factors on the regional demographic indicators in all pre-reform Latvian municipalities during 2011 and 2019

\begin{tabular}{|c|c|c|c|c|c|c|c|c|}
\hline Factors & \multicolumn{4}{|c|}{ Linear model (LM) } & \multicolumn{4}{|c|}{ Spatial Lag Model (SLM) } \\
\hline $\begin{array}{l}\text { Proximity of reg. } \\
\text { dev. centre }(2019)\end{array}$ & $\begin{array}{l}-0.05087^{* \pi *} \\
(0.01501)\end{array}$ & $\begin{array}{l}-0.00650 \\
(0.01715)\end{array}$ & $\begin{array}{l}-0.01253 \\
(0.01387)\end{array}$ & $\begin{array}{c}0.43813 \\
(0.54334) \\
\end{array}$ & $\begin{array}{c}-0.04510^{* *} \\
(0.01439)\end{array}$ & $\begin{array}{c}0.01100 \\
(0.01411)\end{array}$ & $\begin{array}{r}-0.00398 \\
0.01166 \\
\end{array}$ & $\begin{array}{c}0.75206 \\
(0.50766) \\
\end{array}$ \\
\hline $\begin{array}{l}\text { Average priv. wages! } \\
(2017)\end{array}$ & $\begin{array}{ll}1 & -0.00000 \\
1 & (0.00001) \\
\end{array}$ & 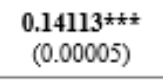 & $\begin{array}{c}0.00019 * \div \dot{z} \\
(0.00004)\end{array}$ & 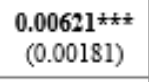 & $\begin{array}{l}-0.00003 \\
(0.00005)\end{array}$ & $\begin{array}{l}0.00014^{i *} \\
(0.00005)\end{array}$ & $\begin{array}{l}0.00009 * * \\
(0.00004)\end{array}$ & $\begin{array}{c}0.00417^{*} \\
0.00177\end{array}$ \\
\hline $\begin{array}{l}\text { Unemployment } \\
\text { (2019) }\end{array}$ & $\begin{array}{c}0.00130 \\
(0.00186) \\
\end{array}$ & $\begin{array}{c}-0.00503 * \\
(0.00203)\end{array}$ & $\begin{array}{l}-0.00120 \\
(0.00164)\end{array}$ & $\begin{array}{c}-0.22363^{* * *} \\
(0.06440)\end{array}$ & $\begin{array}{c}0.00220 \\
(0.00176)\end{array}$ & $\begin{array}{l}-0.00240 \\
(0.00173)\end{array}$ & $\begin{array}{l}-0.00081 \\
(0.00139)\end{array}$ & $\begin{array}{c}-0.15642^{* *} \\
0.06457\end{array}$ \\
\hline $\begin{array}{l}\text { Spatially lagged } \\
\text { dependant variable }\end{array}$ & 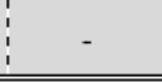 & - & - & - & $\begin{array}{c}-0.28754^{*} \\
0.11433 \\
\end{array}$ & $\begin{array}{c}\mathbf{0 . 5 9 4 2 8 * * *} \\
(0.07689) \\
\end{array}$ & $\begin{array}{c}0.58496 * * * \\
(0.08294) \\
\end{array}$ & $\begin{array}{c}0.33201^{*} \\
0.10207 \\
\end{array}$ \\
\hline
\end{tabular}




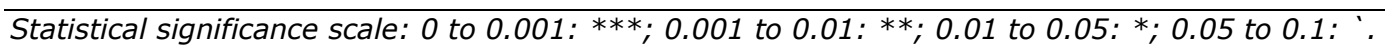

\section{Source: author's calculations based on SCB, 2021}

Model estimations confirm provisional observations about the limited role of regional development centres in the population number dynamics of the rural areas. However, both models show that presence or proximity of the regional development centres has significant positive effect on the gender ratio (i.e. making these areas more attractive to working age females). This corresponds to the findings of previous studies (Klüsener S., 2006), and may prove demographically important in the long-term perspective.

Gender ratio was found to be a significant positive factor for net migration and number of children. SLM model has also shown some limited but noticeable spatially distributed effect on total population change, which can be attributed to the population mobility. Unsurprisingly, average wages in private sector were found highly significant for all dependant demographic indicators except gender ratio, while unemployment level was shown to be the most significant explanatory factor for lower shares of population below working age.

Considering the two selected economic sectors, models indicate that information and communication technology (ICT) sector shows high positive impact on total population growth and significant impact on net migration, irrespectively of geographical location. This sector also has some impact on reduction of the gender ratio. On the other hand, agriculture as main employment option has clear negative impact on the gender ratio, total population growth and net migration. However, negative impact on total population growth and net migration was much less evident in SLM model, suggesting that population mobility between municipalities can alleviate some negative effects of limited employment choices.

Finally, spatial lag factor was found highly significant for total population growth and positive net migration. The role of spatial spill-overs was much lower for proportion of population below working age and gender ratio. This is a very important observation, considering the small size of municipalities under study. It clearly illustrates the negative impact of daily mobility on the natural population growth and family formation (Ruger, H. and Viry, G., 2017).

In summary, model results have shown that regional development centres in general and particularly those located in remote areas have little or no direct effect on the population dynamics. However, regional development centres offer more diverse employment opportunities and essential social services, making them more attractive to working age females and households with children. Income levels are most important in determining net migration flows, while stable and equal employment opportunities, as well as lower gender ratio, play crucial role in natural demographic change. Due to negative effects on family formation, unnecessary daily mobility should be minimised, particularly for the working age female population.

These findings outline a scale of challenges faced by reformed rural municipalities and their corresponding development centres. Based on the limited success stories (see Table 1) and model estimations (see Table 2), our advice would be to expand suburban areas of development centres to encompass bigger parts of their new municipalities. At the same time, it would be just as crucial to diversify employment opportunities at the regional development centres and improve their accessibility from their adjacent territories. Strong positive role of the ITC sector in the demographic development suggests that focus on location-independent employment and services is an important route to explore in the future rural development setting. 


\section{Conclusions, proposals, recommendations}

1) Literature sources provide several key directions for addressing rural depopulation, including facilitating stronger social ties, improved commuting and digitalisation. Some studies suggest focusing specifically on gender-equal employment opportunities and family-friendly spaces to avoid female outmigration from rural areas.

2) Analysis confirms a core-periphery distribution of the demographic development trends in Latvian municipalities, suggesting possible categorisation of the municipalities by the associated demographic risks, as proposed by the literature. Administrative-territorial reform has not affected the overall coreperiphery setting of demographic development.

3) Spatial and model-based analysis conform with the literature, showing that limited employment opportunities and increased spatial mobility associated with life in Latvia's rural areas may harm private life domains such as family formation and fertility, resulting in severe depopulation risks.

4) Regional development centres located in remote areas show little or no immediate effect on the population dynamics. However, these centres offer more diverse employment opportunities and essential social services, making them more attractive to working age females and households with children.

5) Supporting and developing local industries, public services and infrastructure facilitating better employment options and equal opportunities for working age females is a paramount condition for slowing or reversing rural depopulation.

6) Significant influence of the ITC sector in local demographic processes supports the idea that digitalisation, as well as focus on location-independent employment and services, will play major role in the future rural demographic development.

\section{Acknowledgements}

This study was supported by National Research Programme "Latvian heritage and future challenges for the country's sustainability" Project No. VPP-IZM-2018/1-0015 "Towards sustainable development and inclusive society in Latvia: response to demographic and migration challenges" (DemoMig).

\section{Bibliography}

1. BiB (2018). Many Women Move Workplace Closer to Their Home after First Childbirth. Press Release of the German Federal Institute for Population Studies. Retrieved: https://www.bib.bund.de/EN /Service/Press/2018/pdf/2018-08-Many-Women-Move-Workplace-Closer-to-Their-Home-after-FirstChildbirth.pdf. Access: 15.01.2021.

2. Camarero, L., Sampedro, R. (2016). Exploring Female Over-Migration in Rural Spain - Employment, Care Giving and Mobility. In: Wiest K. (eds) Women and Migration in Rural Europe. New Geographies of Europe. Palgrave Macmillan, London.

3. Central Statistics Bureau of Latvia [CSB], (1961). Численность, состав, естественный прирост и миграция населенис Латвийской ССР. Number, Composition, Natural Movement and Migration of Population in Latvian SSR. Collection of statistical data. Riga.

4. Cipin, I., Klusener, S., Recano, J., Ulceluse, M. (Ed.) (2020). A Long-term Vision for the Development of Rural Areas in Europe: Insights from Demography. Population and Policy Brief, No. 27. Berlin: Population Europe. Retrieved: https://population-europe.eu/policy-brief/long-term-vision-development-rural-areas-europe. Access: 16.12.2020.

5. Cross-Sectoral Coordination Center [CCC], (2020). National Development Plan of Latvia 2021 - 2027.

6. CSB (2020a). Demography. Collection of Statistics. Retrieved: https://www.csb.gov.Iv/en/statistics/ statisticsby-theme/population. Access: 07.03.2021

7. CSB (2020b). Densely Populated Areas dataset. Retrieved: https://data.gov.lv/dati/dataset/bat. Access: 20.12.2020.

8. CSB (2021). Statistical Yearbook of Latvia. Riga.

9. Dijkstra, L., Poelman, H. (2014). A Harmonised Definition of Cities and Rural Areas: the New Degree of Urbanisation. European Commission Working Paper No. 01/2014. Retrieved: https://ec.europa.eu/ regional_policy/sources/docgener/work/2014_01_new_urban.pdf. Access: 09.03.2021. 
10. Ermisch, J. and Mulder, C., H. 2019. Migration versus Immobility, and Ties to Parents. European Journal of Population. Volume 35, Issue 3, pp. 587-608.

11. Franic R., Kovacicek, T. (2019). The Professional Status of Rural Women in the EU. European Parliament report PE 608.868. Retrieved: https://www.europarl.europa.eu/RegData/etudes/STUD/2019/608868/IPOL_ STU(2019)608868_EN.pdf. Access: 10.02.2020.

12. Hasek, O. (2020). Regionální diferenciace plodnosti podle typologie venkova. The Regional Differentiation of Fertility by Rural Typology in Czechia. Demografie. Volume 62, pp. 3-13.

13. Hill, K. (2013). Why Do Fertility Levels Vary between Urban and Rural Areas? Regional Studies. Volume 47, Issue 6, pp. 895-912.

14. Kashnitsky, I., Aburto, J. M. (2020). COVID-19 in Unequally Ageing European Regions. World Development, Vol. 136. Retrieved: https://doi.org/10.1016/j.worlddev.2020.105170. Access: 12.02.2021.

15. Klüsener, S. (2006). Lebensgestaltungsmöglichkeiten,-strategien und-ziele ukrainischer Dorfschulabgänger im Kontext von Globalisierung und postsowjetischer Transformation: Zwei Fallstudien in der Zentral-und Südukraine. Life Possibilities, Strategies and Goals of Ukrainian Village School Leavers in the Context of Globalization and post-Soviet Transformation: Two Case Studies in Central and Southern Ukraine. Dissertation. University of Freiburg. Retrieved: https://freidok.unifreiburg.de/fedora/objects/freidok:3487/datastreams/FILE1/content. Access: 22.02.2021.

16. Krumins, J., Berzins, A., Dahs, A. (2020). Regional Demographic Trends in Accordance with the New Model of Territorial Division in Latvia and Future Dynamics in Statistical Regions of the Baltic States. Economic Science for Rural Development Conference Proceedings, Issue 54, pp. 233-240.

17. Ministry of Environmental Protection and Regional Development [MoERPD], (2021). Administrative Territories 2021 dataset. Retrieved: https://data.gov.Iv/dati/dataset/atr. Access: 10.02.2021.

18. Nikodemus, O., Klavins, M., Zelcs, V., Krisjane, Z. eds. (2018). Latvija. Zeme, daba, tauta, valsts. Latvia. Land, Nature, People, Country. Monography. Riga: LU academic press.

19. Ritchie H., Roser M. (2019). Urbanization. Online report. Retrieved: https://ourworldindata.org/ urbanization. Access: 07.03.2021.

20. Rüger, H., Viry, G. (2017). Work-related Travel over the Life Course and Its Link to Fertility: A Comparison between Four European Countries, European Sociological Review, Volume 33, Issue 5, pp. 645-660

21. Saeima (2020). Law on Administrative Territories and Populated Areas.

22. State Land Service of Latvia [SLS], (2016). Generalised Administrative Boundaries Dataset. Retrieved: https://latvija.Iv/lv/PPK/Maja-un-vide/Zemes-izmantosana/p3421. Access: 20.12.2020.

23. Stonawska, K., Vaishar, A. (2018). Differentiation and Typology of the Moravian Countryside. European Countryside. Volume 10, pp.127-140.

24. United Nations [UN] (2018). World Urbanization Prospects: The 2018 Revision. Online edition. Retrieved: https://esa.un.org/unpd/wup. Access: 07.03.2021.

25. Ward, M. D. and Gleditsch, K. S. (2008). Spatial Regression Models. Thousand Oaks: Sage, 99 pages. 